\title{
Performance Evaluation of Diverse MANET Routing Protocols - A Review
}

\author{
Sandeep Kaur \\ Lovely Professional University, India
}

\author{
Ketki Arora \\ Lovely Professional University, India
}

\begin{abstract}
MANET is infrastructure less, decentralized multi-hop network where the mobile nodes are free to move randomly, these mean the network topology dynamic, the performance evaluation is major challenges in ad hoc network. Performance evaluation refers to evaluate the performance of MANET routing protocols, there are various performance metrics are used to improve the performance of MANET routing protocols. Performance are evaluated in case of change in traffic, number of nodes, mobility and pause time etc. performance is measured in term of packet delivery ratio, routing load, average jittering and throughput. In

this paper, we review on the various research papers related to the performance evaluation of various routing protocols and performance comparison of routing protocols in MANET, we also provide the overview of MANET routing protocols such as: AODV, DSDV, DSR and ZRP.
\end{abstract}

\section{Keyword:}

MANET, Performance Evaluation, AODV, DSR, ZRP.

\section{INTRODUCTION}

A mobile ad hoc network (MANET) consists of a set of mobile hosts that know how to communicate with each other without the help of base stations. As shown in Fig. 1, the topology of a MANET can be extremely dynamic due to the mobility of mobile nodes. The formation of mobile computing and communication devices (e.g., cell phones, laptops, personal digital assistants) is driving a new change in our information culture. Wireless networks consist of a number of nodes which communicate by each other over a wireless

Channel [1]. There are now two variations of mobile wireless networks: infrastructure networks and infrastructure less networks. The infrastructure networks are the one, in which mobile devices communicate with base stations that are connected to fixed network infrastructure. Each node in the infrastructure networks is within the range of a fixed access point like base station. Infrastructure less wireless networks is a major class of wireless networks that is greatest appropriate for scenarios where there is demand of temporary and localized telecommunication demand. Such networks consist of wireless devices that can form a network alone without the need for pre-deployed telecommunication infrastructures such as base-stations and access points.

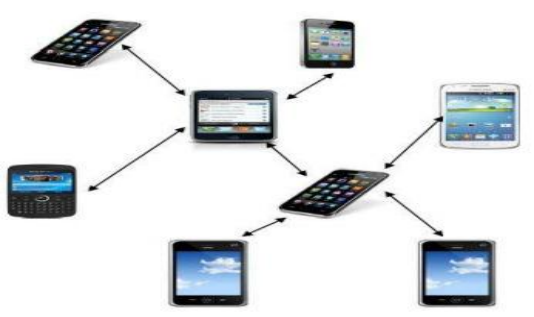

Fig 1: MANET Network [1]

\section{ROUTING PROTOCOLS}

There are many routing protocols has been using in MANET. Each routing protocols has its own pros and cons in different scenario. In MANET, routing protocols has been classified into three categories that are proactive (DSDV, OLDR and WRP), reactive (DSR and AODV) and highbred routing protocols (ZRP and TORA)

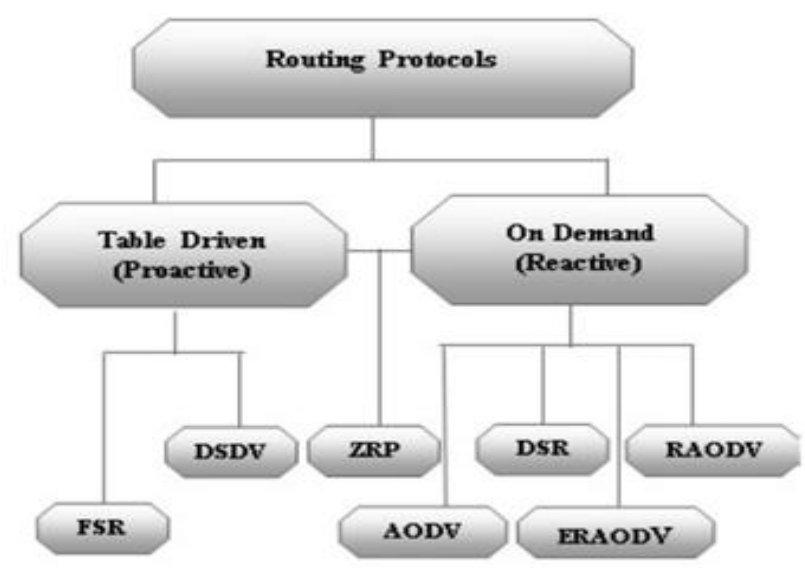

Fig 2: Classification of Routing Protocols [2]

\subsection{Proactive Protocols}

Proactive protocols are also known as table driven protocols because route to each node which are in network maintained in routing table [3] .Packet are transmitted to node as predefined route as in a routing table, the packet forwarding is done faster but routing overhead is greater because all the route have to be defined before sending packet. DSDV are example of proactive protocols.

\subsubsection{Destination sequenced distance vector $(D S D V)$}

DSDV is table driven routing protocol based on the classical Bellman-Ford routing algorithm. In this routing protocol, each mobile node in the system maintains a routing table in which all the possible destinations and the number of hops to thin in the network are recoded. A sequence number is also associated with each route to the destination. The route labeled with the highest sequence number is always used. The data broadcast by each mobile node well contain new sequence number, the destination address, the number of hopes to reach the destination and the sequence number of the information received regarding that destination.

\subsection{Reactive Protocols}

Reactive protocols are also known as on demand routing protocols. This routing Protocol does not keep record of route and routing table so there is no overhead for maintaining the route to nodes. When a path establish in network, the date packet sent immediately to the connected router that will send the request for the new route. The route searching is done using the flooding algorithm which says "just forward the 
packet to their neighbor". This process repeat until it reaches the destination node. These protocol have low overhead of routing information but higher latency. DSR and AODV are example of reactive protocols.

\subsubsection{Dynamic source routing protocol}

DSR is on-demand routing protocol. This protocol has to mechanisms - route discovery and route maintenance. The source route is needed when some node originates a new packet destined for some node by searching its route cache all initiate route discovery using ROUTE REQUEST AND ROUTE REPLY messages. On detecting link break, DSR sends ROUTE ERROR message to source node for new route.

\subsection{Hybrid Protocols}

These types of protocols have combine feature of reactive and proactive protocols and take advantage of both type so hybrid protocol have less time for route discovery and no overhead of routing information. ZRP and TORA are the example of hybrid protocol.

\subsubsection{Zone Routing protocol (ZRP)}

The Zone Routing Protocols approaches by maintaining an up- to-date topological map of a zone centered on each node. ZRP uses proactive approach for routing inside the zone i.e. intra-zone routing protocol (IARP) and reactive approach for routing outside the zone i.e. inter zone.

Table 1: Parametric Comparison of Routing Protocol Strategies [11]

\begin{tabular}{|c|c|c|c|}
\hline Parameters & Reactive & Proactive & Hybrid \\
\hline $\begin{array}{l}\text { Routing } \\
\text { Philosophy }\end{array}$ & Flat & Flat / Hierarchical & $\begin{array}{l}\text { Flat } \\
\text { /Hierarchical }\end{array}$ \\
\hline Routing Scheme & On-Demand & Table-Driven & $\begin{array}{l}\text { Combination of } \\
\text { both }\end{array}$ \\
\hline $\begin{array}{l}\text { Topology } \\
\text { Dissemination }\end{array}$ & Periodical & On-Demand & Both \\
\hline Route Latency & Always available & $\begin{array}{l}\text { Available when } \\
\text { needed }\end{array}$ & Both \\
\hline $\begin{array}{l}\text { Communication } \\
\text { Overhead }\end{array}$ & High & Low & Medium \\
\hline Scalability & $\begin{array}{l}\text { Suitable for smal1 } \\
\text { network }\end{array}$ & Low & $\begin{array}{l}\text { Designed for } \\
\text { large network }\end{array}$ \\
\hline Storage Capacity & Low & High & $\begin{array}{l}\text { Depend upon } \\
\text { zone, as } \\
\text { capacity inside } \\
\text { zone is high }\end{array}$ \\
\hline Types & AODV,DSR,TORA & DSDV,WRP,FSR & ZRP,WARP \\
\hline
\end{tabular}

\section{PERFORMANCE METRICS}

For calculating the performance of different MANET routing protocols, we require both the qualitative as well as quantitative metrics are:

\subsection{Throughput}

Throughput is the number of packet that is passing through the channel in a particular unit of time. This performance metric shows the total number of packets that have been successfully delivered from source node to destination node [12]. Factors that affect throughput include frequent topology changes, unreliable communication, limited bandwidth and limited energy.

$$
\text { Throughput }=\frac{\text { Received } \text { Packet } \text { Size }}{\text { Time to send }}
$$

\subsection{Packet Delivery Ratio (PDR)}

Packet delivery ratio is calculated by dividing the number of packet received at the destination by the number of packet originated at the source [9]. For the best performance packet delivery ratio of routing protocol should be as high as possible. If the ratio is 1 , it will be the best delivery ratio of routing protocol.

$$
\text { PDR }=\frac{\text { Packets Received by the Destination Node }}{\text { (Packets Received }+ \text { Packets dropped })}
$$

\subsection{End to end delay}

This metric includes all possible delay that may be caused by buffering during route discovery, queuing at the interface queue, retransmission delay at the MAC layer, propagation and transfer time [13]. It is defined as the time taken for a data packet to be transmitted across a MANET from source to destination. The E2E metric is given by:

$\mathrm{E} 2 \mathrm{E}=\mathrm{Tr}-\mathrm{Ts}$

Where, Tr is the time that a packet is received and Ts the time that this packet was injected into the network.

\subsection{Packet Dropped}

Packet dropped is the ratio of all same packets at the destination to all transmitted packets from CBR source.

Packet dropped $=$ number of packet send - number of packet received

\subsection{Routing load (RL)}

Routing load is the number of routing packets transmitted for each data packet delivered at the destination. Routing load is determined as [13].

$\mathrm{RL}=\mathrm{Pc} / \mathrm{Pd}$

Where Pc is total control packet sent and Pd is total packet sent.

\subsection{Normalized Routing Load (NRL)}

It is number of routing packets transmitted by each node in a network divided by the number of packets received from the receiver node.

$$
\mathrm{NRL}=\frac{\text { Routing Packets }}{\text { Total Received Packets }}
$$


Table 2: Performance Metrics

\begin{tabular}{|c|c|}
\hline Performance Metrics & Better When \\
\hline Throughput & High \\
\hline Packet Delivery Ratio & High \\
\hline End-to-End Delay & Low \\
\hline Packet Loss & Low \\
\hline Routing Load & Low \\
\hline Normalized Routing Load & Low \\
\hline
\end{tabular}

\section{RELATED WORK}

There are various type of comparison has been performed with the routing protocols. Most researchers shown comparison and performance evaluation of routing protocols by mean of performance metrics. Some researchers study on the performance evaluation of routing protocols by using the various performance metrics and some on the performance comparison of routing protocols in MANET. While most of the work relate to the performance evaluation of MANET routing protocol include reactive, proactive and hybrid protocols. The performance evaluation of diverse MANET routing protocols has been demonstrated in Table 2

Table 3: Performance Evaluation of Various Routing Protocols.

\begin{tabular}{|c|c|c|c|c|c|}
\hline Authors name & $\begin{array}{l}\text { Protocols } \\
\text { Evaluated }\end{array}$ & A rea Size & $\begin{array}{l}\text { Variable } \\
\text { Parame ters }\end{array}$ & $\begin{array}{l}\text { Performance } \\
\text { Metries }\end{array}$ & Conclusion \\
\hline Reena et al. [3] & $\begin{array}{l}\text { DSR,TORA, } \\
\text { LFACH }\end{array}$ & $500 * 500$ & No. of nodes & $\begin{array}{l}\text { Throughput, end- } \\
\text { to-end delay, } \\
\text { jitter, PDR }\end{array}$ & $\begin{array}{l}\text { DSR is much better because } \\
\text { of higher PDR and } \\
\text { Throughput. TORA and } \\
\text { L.FACH best in case of end- } \\
\text { to -end delay. }\end{array}$ \\
\hline $\begin{array}{l}\text { Divangna et } \\
\text { al. [4] }\end{array}$ & $\begin{array}{l}\text { DSDV,DSR, } \\
\text { AODV,ZRP }\end{array}$ & $1200 * 1200$ & No. of nodes & $\begin{array}{l}\text { PDR, Average } \\
\text { Throughput, } \\
\text { Routing } \\
\text { Overhead, } \\
\text { A verage Delay }\end{array}$ & $\begin{array}{l}\text { AODV best in case of } \\
\text { average throughput and } \\
\text { PDR } Z R P \text { best in case of } \\
\text { average delay and routing } \\
\text { overhead. }\end{array}$ \\
\hline $\begin{array}{l}\text { Zaibalshrat et } \\
\text { al.[5] }\end{array}$ & $\begin{array}{l}\text { DSDV,DSR, } \\
\text { ZRP }\end{array}$ & $500 * 500$ & $\begin{array}{l}\text { No, of nodes, } \\
\text { Pause time }\end{array}$ & $\begin{array}{l}\text { Packet delivery } \\
\text { fraction and } \\
\text { Throughput }\end{array}$ & $\begin{array}{l}\text { DSR performance is better } \\
\text { for both PDF and } \\
\text { Throughput. When pause } \\
\text { time less throughput low for } \\
\text { all DSDV, DSR and ZRP. } \\
\text { DSR is better. }\end{array}$ \\
\hline $\begin{array}{l}\text { AshishK.Murya } \\
\text { et al. [6] }\end{array}$ & $\begin{array}{l}\text { AODV,FSR, } \\
\text { ZRP }\end{array}$ & $1500 * 1500$ & $\begin{array}{l}\text { No. of nodes, } \\
\text { Pause time }\end{array}$ & $\begin{array}{l}\text { A verage end-to- } \\
\text { end delay, PDR, } \\
\text { Throughput, } \\
\text { A verage jitter }\end{array}$ & $\begin{array}{l}\text { AODV show best } \\
\text { performance in case of PDR } \\
\text { and throughput } \\
\text { FSR and ZRP show lowest } \\
\text { end-to-end delay. }\end{array}$ \\
\hline $\begin{array}{l}\text { PreetiGaharw ar } \\
\text { et al. [7] }\end{array}$ & $\begin{array}{c}\text { DSDV,AODV, } \\
\text { DSR }\end{array}$ & $2000 * 500$ & No. of nodes & $\begin{array}{l}\text { A verage end-to- } \\
\text { end delay, PDR, } \\
\text { Packet dropped }\end{array}$ & $\begin{array}{l}\text { AODV show best } \\
\text { performance than DSR and } \\
\text { DSDV in term of average } \\
\text { end-to-end delay, no. of } \\
\text { packet dropped and PDR. so } \\
\text { AODV is better. }\end{array}$ \\
\hline $\begin{array}{l}\text { GinniTonk et } \\
\text { al. [8] }\end{array}$ & $\begin{array}{l}\text { AODV,DSR, } \\
\text { DSDV }\end{array}$ & $800 * 800$ & $\begin{array}{l}\text { No. of nodes, } \\
\text { Pause time, } \\
\text { Maximum } \\
\text { speed }\end{array}$ & $\begin{array}{l}\text { PDR, NRI, } \\
\text { A verage end-to- } \\
\text { end delay }\end{array}$ & $\begin{array}{l}\text { In all case AODV has } \\
\text { highest PDF and NRI. } \\
\text { While DSR has highest } \\
\text { average end-to-end delay. }\end{array}$ \\
\hline $\begin{array}{l}\text { Deepak Kumar } \\
\text { et al. [9] }\end{array}$ & DSDV,AODV & $500 * 500$ & $\begin{array}{l}\text { Maximum } \\
\text { speed }\end{array}$ & $\begin{array}{l}\text { PDR, Average } \\
\text { end-to-end delay }\end{array}$ & $\begin{array}{l}\text { AODV suffer in term of } \\
\text { PDF but give better } \\
\text { performance in term of end- } \\
\text { to-end delay. DSDV } \\
\text { perform better in case of } \\
\text { PDF and suffer in term of } \\
\text { end-to-end delay. }\end{array}$ \\
\hline $\begin{array}{l}\text { A Rama Rao et } \\
\text { al. [10] }\end{array}$ & ${ }_{\text {ZRP }}^{\text {AOMDV }}$ & $1600^{*}=2550$ & No. of nodes & $\begin{array}{l}\text { End-to-end delay, } \\
\text { PDR, } \\
\text { Throughput }\end{array}$ & $\begin{array}{l}\text { When no. of nodes less, } \\
\text { ZRP has less delay but } \\
\text { when increase high delay } \\
\text { than DSR and AOMDV. } \\
\text { AOMDV has high PDR. } \\
\text { AOMDV performance is } \\
\text { better. }\end{array}$ \\
\hline
\end{tabular}

\section{CONCLUSION}

In this paper an effort has been made on the performance evaluation of various routing protocols such as proactive, reactive and hybrid protocols. There are different kind of parameters are available for performance evaluation of various routing protocols. We analyzed that each protocol has different behavior in the network and we conclude that the AODV (Ad-Hoc on-demand distance vector) and DSR ( Dynamic Source Routing) protocol is best and efficient which has high throughput, less packet dropped, low NRL and higher PDR. The protocol which offer low routing load is efficient routing protocol. These parameters have great role to select the efficient routing protocols in any communication network. 


\section{REFRENCES}

[1] Swati Puri, Vishal Arora "Routing Protocols in MANET" In International journal of computer application, june 2014

[2] Arshad Shaikh, Danish Vason "Performance Analysis of MANET Routing Protocol-A comparative study',In International journal of computer application, 2013.

[3] Reena, RekhaPandit "Performance evaluation of routing protocols for MANET using NS2", In international journals of computer application. March,2013

[4] Divangna Gupta "Simulation of Different Routing Protocols In MANET”' In IJSRP, Aug 2014.

[5] ZaibaIshrat "Performance evaluation Of DSDV, DSR and ZRP Protocol in MANET"' in IJCAT, 2013.

[6] AshishK.Maurya "Simulation Based Performance Comparison of AODV, FSR and ZRP Routing Protocols in MANET" In international journal of computer applications, Nov 2010.

[7] PreetiGaharwar, "Performance comparison of Routing Protocols" in IJARCCE, Apr 2013.
[8] GinniTonk "Performance comparison of Ad-hoc Network Routing Protocol using NS2" In IJITEE, June 2012.

[9] Deepak Kumar "Performance Comparison of DSDB and AODV Routing Protocol in MANET', in IJECCT, May 2012.

[10] A RemaRao, N.Murali Vishnu " Performance Evaluation of DSR, AOMDV and ZRP routing Protocol in MANET using NS2" In International journal of computer science and information technologies , 2014.

[11] Jatin Gupta, Nivit Gill “ A Review of performance evaluation of routing protocols in MANET", In IJARCTS, 2014.

[12] M Ravi Kumar, Dr. N.Geetanjli "Performance evaluation of AODV and FSR routing protocols in MANET" ,In GJCST-E,2013.

[13] Alexandros Kaponias "Simulation and Evaluation of MANET Routing Protocols forEducational Purpose" In PACET,2014. 